\title{
GEOLOGY
}

UDC $624.131(477)$

L. S. Koriashkina ${ }^{1}$, Cand. Sc. (Phys.-Math.),
orcid.org/0000-0001-6423-092X,
T.P. Mokritska ${ }^{2}$, Dr. Sc. (Geol.), Assoc. Prof.,
orcid.org/0000-0002-1152-0699,
O. V. Bondar ${ }^{2}$ Cand. Sc. (Geol.), Assoc. Prof.,
orcid.org/0000-0002-7860-5750,
M. M. Odnovol ${ }^{1}$,
orcid.org/0000-0002-2022-7996
DOI: $10.29202 /$ nvngu/2018-5/2

1 - National Mining University, Dnipro, Ukraine, e-mail: koriashkinals@gmail.com; odnovol.m.m@nmu.one 2 - Oles Honchar Dnipro National University, Dnipro, Ukraine, e-mail: mokritska@i.ua; olessiabondar@ukr.net

\section{ON THE INFLUENCE OF THE NUMBER OF AGGREGATES AND FREE PARTICLES ON THE SUBSIDENCE OF LOESS SOILS}

Purpose. Studying connections between microstructure of loess soil and its subsidence on the example of the Pleistocene deposits of the Middle Dnipro river region.

Methodology. Experimental and mathematical research methods. The aggregate structure was defined using the improved Ryaschenko's "Microstructure" methodology. Indicators of subsidence were defined according to the current standards of Ukraine. Impact of degradation of microaggregate composition on subsidence was defined with the help of Group method of data handling (GMDH).

Findings. Properties of samples of loess-like suppositories, loams and clays, selected from the outcrops within Dnipro and Dnipro region (Vilnohirsk, Kryvyi Rih, Novomykolaiivka village) were studied. The total number of the selected samples is 71. In addition to the methodology for studying granulometric composition of dispersed soils, a way for preparing soil for analysis, which allows clarifying the area of dynamic changes of dispersion, was introduced. The components of the aggregates were predominantly thin-luminescent (in the Dofinivskyi ( $e$ PIII $d f$ ), the Udaiskyi ( $v d$ PIII ud), the Dniprovskyi ( $v d$ PII $d n$ ) horizons) and large-peal particles (the Vitachevskyi horizon $e$ PIII $v t$ ), which are released when the aggregates collapse during soil subsidence. There were considered different variants of choosing variables for explaining mathematical model of degradation of loess subsidence in a region of aggregation due to increasing humidity with using Group method of data handling. First of all, standard indicators of dispersion and physical properties of the soil were taken into account. At the next stage, four sets of variables were considered humidity, the content of individual fractions or changes in the content of fractions after the compression test. It was proven that distribution of free and bound particles, aggregates of sandy, dusty and clay fractions of loess soils of the Middle Dnipro river region together with the indicators of physical state of soil affect the value of relative subsidence of the horizons. Physical state and soil dispersion significantly affect the value of subsidence, regardless of the genesis of the soil. The constructed functional dependency confirms that soil moisture and density have a more significant value than the fraction content. The research results show that the content of bound thin dusty and clay particles is a factor of subsidence on the stage of loss of structural strength $(0.1 \mathrm{MPa})$ and at additional loads. A decrease in the size of released particles with increasing pressure is natural. This pattern is violated in zones of technogenic transformation of the soil structure.

Originality. Functional dependence of the subsidence of the Pleistocene loess sediments on the degradation of the microaggregate composition throughout the range of the discreteness of the solid phase was defined.

Practical value. Necessity of forecasting the degradation of the subsidence properties of loess-like soils in the aeration zone caused by the change in the microaggregate composition throughout the solid phase range was substantiated experimentally and theoretically.

Keywords: microaggregates, subsidence, loess soils, the group method of data handling

Introduction. Numerous scientific papers have been dedicated to investigation of the material composition of loess soils and its influence on subsidence. Popov I.,

(c) Koriashkina L. S., Mokritska T.P., Bondar O. V., Odnovol M. M., 2018
Denisov N. and others believed that the reason of rapid subsidence of loess soils laid in the intense dissolution of highly soluble salts (chlorides, alkaline sulfates, and others). Another group of researchers, including S. Yusupov, I. Sedletskaya, A. Larionov, V. Ananiev, consid- 
ered influence of humidity, porosity of soils, quantitative and qualitative composition of clay minerals, structural features of soils as the main factors of subsidence deformations. Rinsky Y., Veklych M., Kravchenko A., Chasovskikh V., Luvich L. and others dedicated their research studies to investigation of soil composition of the Prydniprovskyi region. In their papers, there is a detailed description of chemical and mineralogical composition of the loess layer, but there is no precise genetic and stratigraphic binding among research objects. Krieger N. introduced the term "degradation", which was developed in the works by V. Korobkin (2004). At the present stage of the development of geological science, more attention is paid to the search for new soil models (F. Bulat, 2005; M. Wang, X. Bai, 2006; L. Donald, Turcotte, 2011). The connection between granulometric composition and fractal dimension was studied on the example of China's loess species (Z. Song, at al., 2015). Osipov V. and Sokolov V., Grigoriev I., Ryaschenko T., Akulova $\mathrm{V}$. and others are actively studying the relations of deformation behavior and microstructure of rocks. The physicochemical theory of effective stresses in soils (V. Osipov) and the contact theory of strength and deformation (P. Lyashenko) were developed. Experimental methods for evaluation of properties (T. Ryaschenko, V.Akulova) and variability of the properties at technogenesis (I. Karelina, T. Tsygankova) are being developed. Methods of stochastic mathematical modeling of property fields and relationships between properties of different nature were developed in the works by V. Pendina, T. Ryaschenko. In the paper by Y.Wang, at al. (2006), violation of particles in the process of compression tests and the connection of this process with the fractal dimensionality of the phases of the soil are studied. The paper by P. Delage, at al. (2005) is dedicated to the connection between the features of the microstructure of the soil and its mechanical behavior. The general model of soil as a dynamic system is developed. But such model does not take into account the fractal distribution of soil particles. The development of new soil models [1, 2] continues. In [2] the results of series of unsaturated soil tests, including direct shear test, hydrostatic triaxial compression test and triaxial shrinkage test are represented. Such experiments were carried out to investigate the influence of structural properties on strength parameters, yielding stress and yielding suction of unsaturated Q3 loess. The current direction of scientific research is application of the fractal theory to the description of the properties of loess soils. For instance, [3] presents an original method for evaluating shear strength of coarse granular rockfill, based on the fractal fragmentation of rockfill particles. In [4] fractal dimensions were used to investigate the characteristics of particle-size distribution in the rhizospheres and bulk soils of six croplands abandoned for 1, 5, 10, 15, 20, and 30 years on the Loess Plateau of China. In [5], focusing on fractal soils, by setting particle and pore surface areas equal and constant, analytical derivations are presented linking all parameters defining soil-water characteristic curves to particle and pore geometry information, size distributions, shapes, volumes and surface areas. The paper [6] is devoted to evaluating fractal and morphological characteristics of a single rock particle. There a large number of particle crushing tests are conducted on a single rock particle.

The state of soils, which corresponds to incomplete water saturation, is investigated [7]. Connection between the features of the structure of loess soils and development of dangerous processes is discovered [8].

The overview of publications in the leading scientific editions of the world indicates an increase in the interest of researchers in the study of processes in complex mechanical dynamic systems from the standpoint of the theory of fractals, stochastic methods for researching self-organization of complex systems.

Presentation of the main research and explanation of scientific results. In conditions of technogenesis, the soil evolves as a multicomponent complex system. The regularities of changes in the dispersity of loess soils during subsidence, which accompany soil degradation, have been studied with the involvement of stochastic data analysis and inductive modeling methods [9]. The properties of samples of loess-like soups, loams and clays, selected from the outcrops within the city of Dnipro and its region (Vilnohirsk, Kryvyi Rih, Novomykolaiivka village) were studied. There was determined granulometric composition and dispersion of the soils, which were tested for subsidence with the method of one and two curves, using four ways of preparation of samples of natural structure. Using group method of data handling (GMDH) for detecting relationships between different parameters describing the state of the soil is explained by a wide spectrum of tasks of data analysis, forecasting and modeling of systems, for the successful solution of which different variants of GMDH algorithms (clear, fuzzy, neurofuzzy and others) are applied.

The standard methodology for determining the granulometric composition of soils does not allow tracking dispersion changes due to violation of the quantity and composition of aggregates. According to the "Microstructure" methodology, the soil for analysis is prepared in three different ways, which provides the ability to determine areas of dynamic variability of dispersion. In this paper, the fourth method for preparation was introduced. Violation of aggregates is carried out by boiling with the addition of ammonia (the standard approach) or sodium pyrophosphoric acid (dispersion preparation). During aggregate preparation, melting and shaking (mechanical or caused by an artificial low magnetic field) are performed. Previously, this technique was not used in Ukraine.

In the paper, the analysis of dispersion and granulometric composition was carried out taking into account the following sizes of fractions: coarse-medium sand $M^{1}(1.00-0.25 \mathrm{~mm})$, fine and very fine sand $M^{2}$ (0.25-0.05 mm), coarse or medium silt $M^{3}(0.05-$ $0.01 \mathrm{~mm})$, fine silt or dust $M^{4}(0.010-0.002 \mathrm{~mm})$, coarse-clayey $M^{5}(0.002-0.001 \mathrm{~mm})$ and thin-clayey $M^{6}(<0.001 \mathrm{~mm})$. The components of the aggregates were predominantly thin-clayey (in the Dofinivskyi (e $P_{I I I} d f$ ), the Udaiskyi (vd $P_{I I I} u d$ ), the Dniprovskyi 
(vd $P_{I I} d n$ ) horizons) and large-grained particles (the Vitachevskyi (e $P_{I I I} v t$ ) horizon), which are released when the aggregates collapse during soil subsidence. Current standards imply indication of the total content of dust and coarse-clayey particles, which does not allow performing detailed analysis of changes in soil dispersion during degradation.

Today, the main method for quantitative forecast of subsidence values is compression testing. The factors of influence on the size of drainage include structural features: the features of the microstructure (elements of the system) and factors that determine the relationships between the elements (mineral composition of the clay fraction, the content and composition of salts, moisture). The standard soil condition indicators (density, humidity, and others) implicitly depend on the combination of the above factors, therefore, the establishment of relations between them and the content of fractions, the values of subsidence is an important stage in the analysis of the causal relationships.

The pressure range, at which tests on subsidence are carried out, can be divided into three stages: the first one specifies a state in which the structural strength of soils is not disturbed $(0.05-0.1 \mathrm{MPa})$; the second one determines the pressure within which there is a violation of the structure $(0.01-0.15 \mathrm{MPa})$; the third one corresponds to an additional load in the conditions of the broken structure of the soil (the load is more than $0.2 \mathrm{MPa}$ ).

Stochastic analysis of the results of laboratory studies of soil properties was performed using the trial version of the "STATISTICA" software with the methodology [11]. The total number of samples considered was 71. Various options for selecting variables were processed. First of all, the standard variables of soil dispersion and properties were selected as variables: the content of particles of size less than $0.002 \mathrm{~mm}\left(M^{9}\right)$ and the total content of particles of size of $0.05-0.002 \mathrm{~mm}$ $\left(M^{11}\right)$, total content of aggregates $\mathrm{A}$, natural moisture $\omega$, pct.; limits of plasticity $\omega_{L}, \omega_{p}$, pct.; maximum molecular moisture content $\omega_{m m c}$, pct.; density of soil at natural moisture content $\rho, \mathrm{gr} / \mathrm{cm}^{3}$. During regression analysis of the whole sample, it was not possible to find connection between the indicators with soil depression.

Other parameters were selected as variables in the study of loess soil dispersion and during construction of bond models using the GMDH algorithm. Four variants of the set of variables were proposed.

Using data about samples of the Kodakskyi, Prichernomorskyi and Dofinivskyi horizons, we constructed the following model of the influence of the aggregates of different sizes, maximum molecular moisture content and soil density on the magnitude of relative subsidence (pressure 0.05 MPa) (1)

$$
\begin{aligned}
\varepsilon_{S L_{0.05}}= & -0.004 \rho+0.087 \omega+0.01 \omega_{s}-0.003 M^{11} \omega- \\
& -M^{9}\left(0.001+0.0028 \omega-0.0015 \omega_{s}\right)
\end{aligned}
$$

where $\varepsilon_{S L_{0.05}}$ is relative subsidence, determined by the method of two curves at a degree of normal pressure of
$0.05 \mathrm{MPa} ; \rho$ is soil density, $\mathrm{gr} / \mathrm{cm}^{3} ; \omega$ is natural soil moisture, pct.; $\omega_{s}$ is soil moisture on the verge of slipping, pct.; $M^{11}$ is content of particles of size $0.05-$ $0.002 \mathrm{~mm}$, pct.; $M^{9}$ is content of particles of size less than $0.002 \mathrm{~mm}$, pct.

Analysis of the research results on dependence of the relative subsidence value (pressure of $0.05 \mathrm{MPa}$ ) on the above parameters using the obtained model shows the significant influence of the physical condition and soil dispersion on the value of the subsidence regardless of the genesis of the soil. The constructed functional dependence (1) confirms a more significant value of soil moisture and density than the fraction content, provided that the fractions are determined according to the current standard.

At the formation level, the sample $(n=71)$ is statistically inhomogeneous in terms of relative subsidence, the content of individual fractions of free and bound particles and aggregates, natural humidity. The coefficients of variation of the distribution of other indicators vary from 0.05 to 0.15 . It was not possible to construct regression models, but using correlation analysis, a hypothesis for the consistent reduction of the size of aggregates that are destroyed in the process of increasing pressure during degradation was obtained (Fig. 1).

The hypothesis was confirmed during studying of the properties of stratigraphic horizons of a single genesis (Table 1).

With inductive modeling, the following functional connections between the relative subsidence and the content of fraction particles $M^{2}, M^{4-A}, M^{5-A}, M^{6-A}$ as well as the content of aggregates $A$ were obtained

$$
\begin{aligned}
& \varepsilon_{S L_{0.1}}=0.001 \cdot\left(1-M^{6-A}-8 M^{6}+M^{6-A} \cdot M^{6}-\right. \\
& \left.-6 M^{6} \cdot M^{6}-4 M^{3}+5 M^{3} \cdot M^{6}-A+A \cdot M^{6}\right),
\end{aligned}
$$

where $\varepsilon_{S L_{01}}$ is relative subsidence, determined by the method of two curves at a degree of normal pressure of $0.1 \mathrm{MPa} ; M^{6-A}$ is content of particles of size less than $0.001 \mathrm{~mm}$, bonded in aggregates, pct; $M^{6}$ is content of thin-clayey particles $(<0.001 \mathrm{~mm})$, pct; $M^{3}$ is content of primary coarse-grained particles $(0.05-0.01 \mathrm{~mm})$, pct; $A$ is the total content of aggregates, pct.

Formula (2) allows performing profound analysis of the factors within the pressure interval of $0.1-$ $0.3 \mathrm{MPa}$. Based on the analysis of fractional changes and stiffness of bonds, it is possible to establish the regularities of evolution of dispersion during degradation from natural to technogenically-modified conditions (Tables 2, 3). The content of bound fine dusty and clay particles and aggregates is a subsidence factor both at the stage of loss of structural strength $(0.1 \mathrm{MPa})$ and at the pressure in the zone of the structure impact (Table 3).

The peculiarities of degradation of the structure of fossil paleoground horizons were studied on the example of Kodakskyi (e PII kd) and Vitachevskyi (e PIII vt) horizons, samples of which were selected from the upper side of the Rybalskyi career and from the slopes of the erosion systems in the Sazhevka dene. 


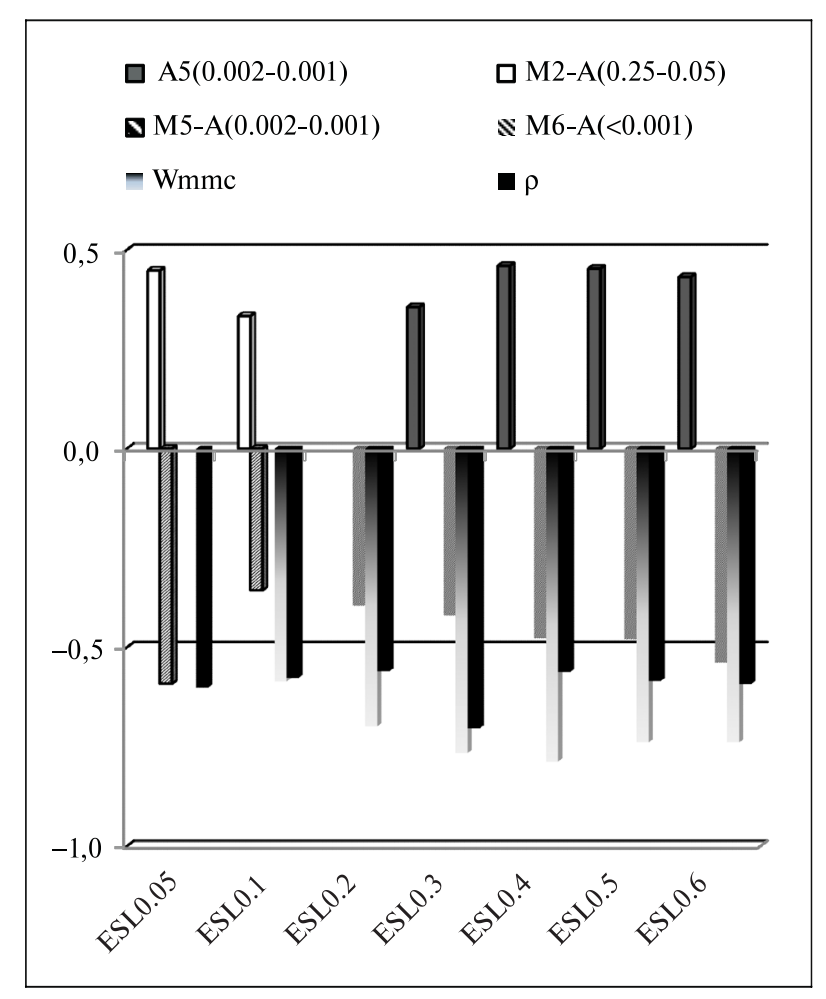

Fig. 1. Dependency graph of the correlation coefficient between the values of the physical state of the sample and the content of individual particle fractions, connected in aggregates, and the number of aggregate:

ESL0.05-ESL0.3 - relative subsidence, determined with the method of two curves within the pressure interval 0.05$0.3 \mathrm{MPa} ; \mathrm{A5}$ (0.002-0.001) - content of aggregates of size 0.002-0.001 mm, pct.; M 2-A (0.25-0.05) - content of particles of size $0.25-0.05 \mathrm{~mm}$, bonded in aggregates, pct.; M5-A (0.002-0.001) - content of particles of size 0.02$0.001 \mathrm{~mm}$, bonded in aggregates, pct.; M6- $A(<0.001) \mathrm{con}-$ tent of particles of size less than $0.001 \mathrm{~mm}$, bonded in aggregates, pct.; $\rho-$ soil density, $\mathrm{gr} / \mathrm{cm}^{3}$

A statistically homogeneous sample collection of results of determining physical properties, content of particles and aggregates, relative subsidence of small volume was investigated.

The reduction trend of the fraction size affecting the
Table 1

Regression models of relative subsidence of loess-based sediments and the content of free fractional particles of size $0.002-0.001 \mathrm{~mm}\left(M^{5}\right)^{*}$

\begin{tabular}{|c|c|}
\hline Regression model & $A R^{2}$ \\
\hline$\varepsilon_{S L_{0.05}}=0.007 M^{5}$ & 0.48 \\
\hline$\varepsilon_{S L_{0.1}}=0.022 M^{5}$ & 0.36 \\
\hline$\varepsilon_{S L_{0.15}}=0.034+0.029 M^{5}$ & 0.61 \\
\hline$\varepsilon_{S L_{0.2}}=0.043+0.024 M^{5}$ & 0.37 \\
\hline
\end{tabular}

${ }^{*} \varepsilon_{S L_{005}}, \varepsilon_{S L_{01}}, \varepsilon_{S L_{015}}, \varepsilon_{S L_{02}}$ - relative subsidence, determined by the method of two curves at a degree of normal pressure of $0.05,0.1$, 0.15 and $0.2 \mathrm{MPa}$ correspondingly; $A R^{2}$ - corrected value of the determination factor; $M^{5}-$ content particles of size $0.002-0.001 \mathrm{~mm}$

value of subsidence, was confirmed partially, at the initial stages of pressure $(3-5)$

$$
\begin{gathered}
\varepsilon_{S L_{0.1}}=0.003+0.001 M^{2} ; \\
\varepsilon_{S L_{0.15}}=0.014+0.001 \cdot A^{4} \cdot\left(-3+M^{2}\right)+ \\
+0.001 \cdot A^{1} \cdot\left(1-M^{4}\right) ; \\
\varepsilon_{S L_{0.2}}=-0.013+0.0016 \cdot M^{2}+0.009 \cdot A^{1} .
\end{gathered}
$$

The set of variables includes the number of fine and very fine sand, coarse or medium silt, fine silt or dust particles.

The type of equations defining connections between the subsidence and dispersity of the eluvial loams of the Dofinivskyi horizon (e PIII $d f$ ) and the eluvial loaches of the Vitachevskyi horizon ( $e$ PIII vt) in the area of influence of the dwelling house was changed (6-9)

$$
\begin{aligned}
& \varepsilon_{S L_{005}}=0.001 \cdot M^{4} \text {; } \\
& \varepsilon_{S L_{0.15}}=-0.088+0.001 \cdot M^{4} \cdot\left(3+M^{4}\left(1+M^{11}\right)+M^{9}\right) \text {; } \\
& \varepsilon_{S L_{0.2}}=-0.055+0.001 M^{11} \\
& \varepsilon_{S L_{0,3}}=0.008+0.001 M^{9} .
\end{aligned}
$$

Table 2

Coefficients at linear components in inductive models of dependence of relative subsidence on the content of particles and aggregates at the degrees of pressure $0.01-0.3 \mathrm{MPa}$ in natural conditions*

\begin{tabular}{|c|c|c|c|c|c|c|c|c|c|}
\hline$\varepsilon_{S L}$ & $A$ & $A^{1}$ & $A^{2}$ & $A^{4}$ & $M^{2}$ & $M^{3}$ & $M^{3-A}$ & $M^{4}$ & $M^{5-A}$ \\
\hline 0.05 & -0.85 & - & - & - & 0.73 & - & - & - & - \\
\hline 0.10 & - & 0.94 & -0.88 & - & - & -0.88 & - & 0.79 & - \\
\hline 0.15 & - & 0.81 & -0.94 & - & - & - & - & - & - \\
\hline 0.2 & - & - & - & - & - & - & 0.73 & - & - \\
\hline 0.25 & - & - & - & 0.81 & - & -0.78 & - & 0.97 & -0.78 \\
\hline 0.3 & - & - & - & 0.76 & - & -0.83 & - & 0.99 & -0.78 \\
\hline
\end{tabular}

${ }^{*} \varepsilon_{S L}$ - relative subsidence, pct.; 0.05 - pressure degree, MPa; $A$ - total content of aggregates, pct.; content of free particles: $M^{2}-$ of size $0.25-0.05 \mathrm{~mm} ; M^{3}$ - of size $0.05-0.01 \mathrm{~mm} ; M^{5}-$ of size $0.002-0.001 \mathrm{~mm} ; M^{6}-$ of size less than $0.001 \mathrm{~mm} ; M^{4-A} ; M^{5-A} ; M^{6-A}-$ fraction particles of size $0.01-0.002 \mathrm{~mm} ; 0.002-0.001 \mathrm{~mm}$ and less than $0.001 \mathrm{~mm}$, bonded in aggregates 
Table 3

Coefficients at linear components in inductive models of dependence of relative subsidence on the content of particles and aggregates at the degrees of pressure $0.01-0.3 \mathrm{MPa}$ in technogenic conditions

\begin{tabular}{|c|c|c|c|c|c|c|c|}
\hline \multicolumn{7}{|c|}{ Coefficients at linear terms of independent variables } & \multirow{2}{*}{ Pressure } \\
\hline$A^{2}$ & $M^{2}$ & $M^{5}$ & $M^{6}$ & $M^{4-A}$ & $M^{5-A}$ & $M^{6-A}$ & 0.05 \\
\hline- & - & -0.002 & - & 0.0016 & - & - & 0.002 \\
\hline-0.002 & - & - & 0.015 & -0.009 & - & 0.008 & 0.15 \\
\hline- & - & 0.008 & 0.014 & 0.002 & - & - & 0.20 \\
\hline- & - & 0.013 & 0.022 & 0.001 & - & - & 0.25 \\
\hline- & - & 0.006 & 0.011 & -0.001 & - & -0.004 & 0.30 \\
\hline- & - & 0.008 & 0.016 & 0.002 & - & & - \\
\hline
\end{tabular}

At the level of stratigraphic-genetic homogeneity, we managed to investigate the samples which include the results of laboratory studies of the properties of the Prichernomorskyi-Dofinivskyi ( $v d$, ed $P_{I I I} p c-d f$ ) and Buzkyi ( $v d R_{I I I} b g$ ) horizons (together); the Dniprovskyi horizon; Udaiskyi and Tiasmynskyi horizons (together) (Table 4). The samples are statistically homogeneous, the mean values differ according to the current state (Fig. 2).

Obviously, the total content of aggregates is larger in the Dniprovskyi horizon. The content of free particles of sandy $\left(M^{1}\right)$, fine and very fine sand $\left(M^{2}\right)$ fractions is mainly observed. In the aggregates of the Udaiskyi and
Tiasmynskyi horizons the particles are predominantly thin-clayey, while the aggregates in the Dniprovskyi and the Prichernomorskyi-Buzkyi horizons are characterized by a larger content of fractional fine $\left(M^{2}\right)$ particles (Fig. 3). These very differences affect the peculiarities of the development of subsidence deformations and degradation of soil properties.

The variables affecting the relative subsidence value were the content of aggregates, free and bound particles and natural moisture. In this case, the following dependence can be traced: with increasing pressure, the influence of the content of finer fractions on the relative subsidence increases $\left(M^{6}\right)$ (Table 5).

Table 4

The coefficients of the linear terms of the inductive models of connections between relative subsidence and the dispersion characteristics of loess sediments, selected and tested in different conditions*

\begin{tabular}{|c|c|c|c|c|c|c|c|c|}
\hline \multirow{2}{*}{ Conditions } & \multicolumn{7}{|c|}{ Coefficients at the independent variables } & \multirow{2}{*}{ Pressure, $\mathrm{MPa}$} \\
\hline & $A^{2}$ & $M^{2}$ & $M^{3}$ & $M^{4}$ & $M^{4-A}$ & $M^{5}$ & $M^{6-A}$ & \\
\hline \multirow[t]{5}{*}{1} & - & - & - & - & 0.001 & - & - & 0.05 \\
\hline & -0.001 & - & - & 0.01 & 0.005 & 0.005 & - & 0.15 \\
\hline & - & - & - & 0.007 & 0.003 & 0.023 & - & 0.2 \\
\hline & 0.002 & - & - & 0.016 & 0.001 & 0.017 & 0.007 & 0.25 \\
\hline & 0.001 & - & - & 0.004 & 0.001 & 0.018 & 0.003 & 0.3 \\
\hline \multirow[t]{6}{*}{2} & $A^{2}$ & $A^{1}$ & $M^{2}$ & $M^{3}$ & $M^{4}$ & $M^{5-A}$ & $M^{6-A}$ & Pressure, $\mathrm{MPa}$ \\
\hline & 0.002 & -0.002 & 0.008 & 0.032 & -0.041 & - & - & 0.1 \\
\hline & - & - & 0.004 & 0.003 & 0.011 & - & - & 0.2 \\
\hline & - & - & - & - & 0.018 & - & -0.007 & 0.3 \\
\hline & - & -0.009 & - & - & 0.015 & - & - & 0.5 \\
\hline & - & -0.007 & -0.001 & 0.0028 & 0.015 & - & - & 0.6 \\
\hline \multirow[t]{6}{*}{3} & $A^{2}$ & $A^{3}$ & $M^{6}$ & $M^{3}$ & $M^{4-A}$ & $M^{5-A}$ & $M^{6-A}$ & Pressure, $\mathrm{MPa}$ \\
\hline & 4808.9 & 248.9 & -32880 & 192.52 & 3155.8 & - & -20.17 & 0.05 \\
\hline & - & - & 0.002 & - & -0.004 & - & - & 0.2 \\
\hline & -2.717 & 0.42 & -771.8 & -0.7481 & -19.074 & -0.251 & -29.263 & 0.3 \\
\hline & - & - & -0.162 & - & 0.003 & - & - & 0.4 \\
\hline & -0.002 & - & 0.263 & 0.001 & 0.004 & 0.002 & - & 0.5 \\
\hline
\end{tabular}

* conditions: 1 - volume of the ring of compression device $50 \mathrm{~cm}^{3} ; 2$ - volume of the ring $100 \mathrm{~cm}^{3} ; 3$ - impact zone of the structure - residential building 


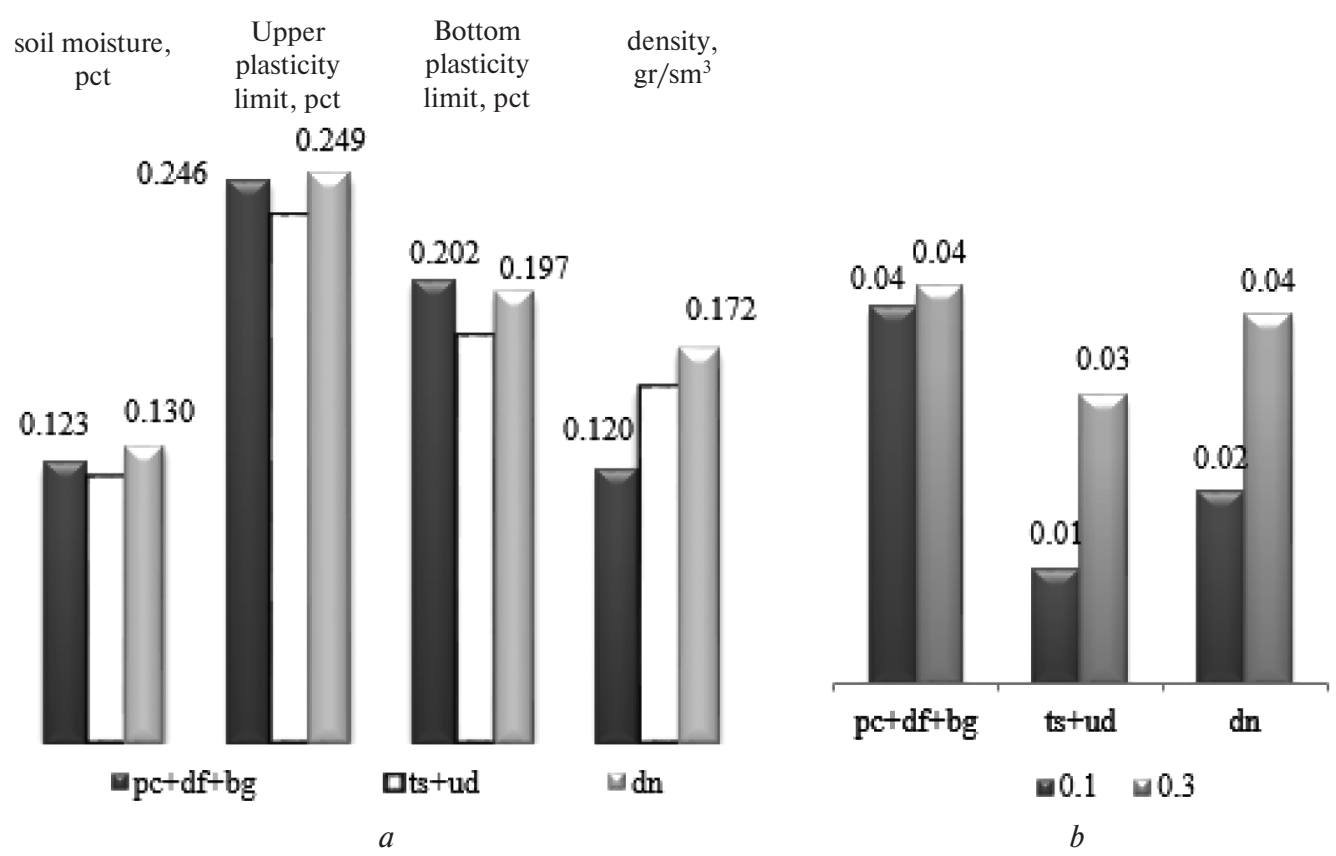

Fig. 2. Average values of selected properties subaerial loess deposits of the Prichernomorskyi-Dofinivskyi (vd, ed $\left.P_{I I I} p c\right)$, Buzkyi (vd $\left.P_{I I I} b g\right)$; Tiasmynskyi ( $\left.v d P_{I I} t s\right),\left(v d P_{I I I} u d\right)$ and Dniprovskyi $\left(v d P_{I I} d n\right)$ horizons:

$a$ - average indicators of physical properties; $b$ - average indexes of subsidence at the degrees of pressure 0.1 and $0.3 \mathrm{MPa:pc}+d f+b g$, $t s+u d$, dn Prichernomorskyi-Dofinivskyi (vd, ed $\left.P_{I I I} p c\right)$, Buzkyi (vd $\left.P_{I I I} b g\right)$; Tiasmynskyi ( $\left.v d P_{I I} t s\right)$, Udaiskyi $\left(v d P_{I I I} u d\right)$ and Dniprovskyi $\left(v d P_{I I} d n\right)$ horizons; 0.123 - mean selective value of natural moisture content of the Prichernomorskyi-Dofinivskyi-Buzkyi deposits; 0.1 - normal pressure in determining the relative subsidence by the method of two curves on the pressure stage $0.1 \mathrm{MPa}$
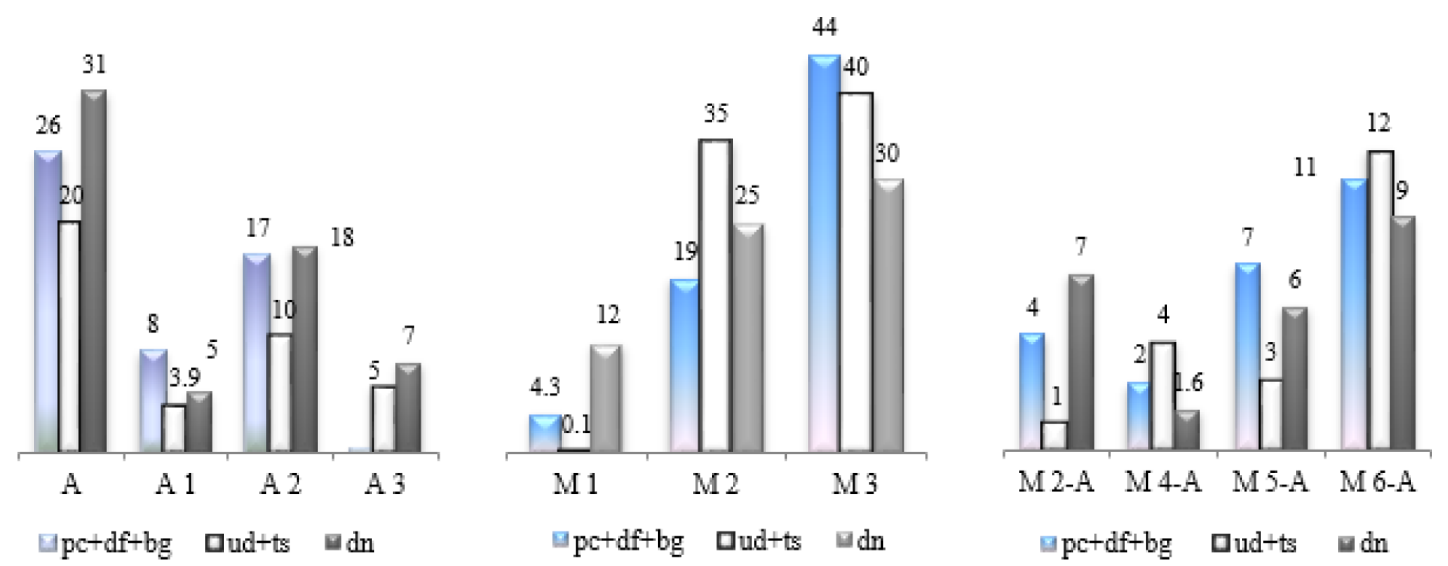

Fig. 3. Features of the distribution of aggregates, free and bound particles in the Prichernomorskyi-Buzkyi, Udaiskyi, Tiasmynskyi and Dniprovskyi horizons

Table 5

Coefficients at linear terms of a deterministic model of the dependence of subsidence subaerial horizons on their dispersion and natural moisture in the field of natural and additional loads*

\begin{tabular}{|c|c|c|c|c|c|c|c|c|}
\hline \multirow{2}{*}{ Complex } & \multicolumn{7}{|c|}{ Independent variables } & \multirow{2}{*}{ Pressure, $\mathrm{MPa}$} \\
\hline & $A^{2}$ & $M^{3}$ & $M^{4}$ & $M^{4-A}$ & $M^{5}$ & $M^{5-A}$ & $M^{6}$ & \\
\hline \multirow{2}{*}{$\begin{array}{l}\mathrm{vd}, \text { ed } P_{\mathrm{III}} \mathrm{pc} \\
\text { vd } P_{\mathrm{III}} \mathrm{bg}\end{array}$} & + & + & 0.0016 & 0.004 & -0.0015 & - & 0.006 & 0.1 \\
\hline & -0.001 & + & -0.003 & - & 0.00468 & -0.0036 & 0.077 & 0.3 \\
\hline \multirow{3}{*}{$\begin{array}{c}\text { vd } P_{\mathrm{II}} \text { ts } \\
\text { vd } P_{\mathrm{III}} \text { ud }\end{array}$} & $M^{2}$ & $M^{3}$ & $M^{5-A}$ & $M^{6}$ & $M^{6-A}$ & $A^{3}$ & $W$ & Pressure, $\mathrm{MPa}$ \\
\hline & & + & + & -0.008 & + & - & -0.138 & 0.1 \\
\hline & + & + & - & 0.016 & - & -0.032 & 0.217 & 0.3 \\
\hline \multirow[t]{3}{*}{$\mathrm{vd} P_{\mathrm{II}} \mathrm{dn}$} & $A^{2}$ & $M^{2}$ & $M^{3}$ & $M^{4}$ & $M^{6}$ & $M^{6-A}$ & $W$ & Pressure, $\mathrm{MPa}$ \\
\hline & - & - & - & - & + & + & 0.249 & 0.1 \\
\hline & - & + & - & 0.0028 & 0.024 & - & 0.196 & 0.3 \\
\hline
\end{tabular}

${ }^{*}(+)$ - a variable is included, but it is not linear 
Conclusion. The analysis of the results of experimental determinations of the granulometric composition and dispersion of the Pleistocene deposits - the horizons of loess and fossil soils, as well as the analysis of the constructed functional dependences of soil subsidence characteristics on its components and parameters of physical condition at different levels of study indicates that:

- distribution of free and bonded particles, aggregates of sandy, dusty and clay fractions, along with the indicators of the physical state of the soil, affect the values of relative subsidence of the horizons;

- with increasing pressure, the degree of correlation of relative subsidence with the content of finer fractions increases;

- in the natural and technogenically modified conditions, the general tendency to reduce the size of fractions composed of free and bound particles is distorted while pressure increases.

\section{References.}

1. Dean, E.T.R., 2015. Particle mechanics approach to continuum constitutive modelling. Geotechnical Research [e-journal], 2(1), pp. 3-34. DOI: 10.1680/gr.14.00018.

2. Wei, F., Yao, Z.-H., Chen, Z.-H., Su, L.-H., Bao, L.-L. and Li, J.-G., 2015. Influence of structural properties on strength and yielding characteristics of unsaturated Q3 loess. Rock and Soil Mechanics [e-journal], 36(9). DOI: 10.16285/j.rsm.2015.09.015.

3. Xu, Y., Feng, X., Zhu, H. and Chu, F., 2015. Fractal model for rockfill shear strength based on particle fragmentation. Granular Matter, 17(6), pp. 753-761. DOI: 10.1007/s10035-015-0591-z.

4. Song, Z., Zhang, C., Liu, G., Qu, D. and Xue, S., 2015. Fractal Feature of Particle-Size Distribution in the Rhizospheres and Bulk Soils during Natural Recovery on the Loess Plateau, China. PLoS ONE [e-journal], 10(9): e0138057. DOI: 10.1371/journal.pone. 0138057.

5. Russell, A. R., 2014. How water retention in fractal soils depends on particle and pore sizes, shapes, volumes and surface areas. Ge'otechnique [e-journal], 64(5), pp. 379-390. DOI: 10.1680/geot.13.P.165.

6. Wang, Y., Dan, W., Xu, Y. and Xi, Y., 2015. Fractal and morphological Characteristics of Single Marble Particle Cruching in Uniaxial Compression Tests. $A d$ vances in Materials Science and Engineering [e-journal], 10 pages. DOI: 10.1155/2015/537692.

7. Li, P., Vanapalli, S. and Li, T., 2016. Review of collapse triggering mechanism of collapsible soils due to wetting. Journal of Rock Mechanics and Geotechnical Engineeringm [e-journal], 8(2), pp. 256-274. DOI: 10.1016/j.jrmge.2015.12.002.

8. Sadovenko, I.A. and Derevyagina, N.I., 2012. About activation potential of loess landslide massif. Naukovyi Visnyk Natsionalnoho Hirnychoho Universytetu, 2, pp. 80-84. 9. Mokritskaya, T., 2013. The laws of formation and evolution geological environment in Pridneprovsk industrial region. Dniepropetrovsk: Aktsent.

10. Ryashchenko, T. G., Tirskikh, S.A. and Kornilova, T.A., 2015. Physico-mechanical properties of hard rock grounds of the Udokan region building site (for the case of Proterozoic sandstones). Proceedings of Irkutsk State Technical University, 2(97), pp. 83-89.

11. Mokritskaya, T. P. and Koriashkina, L. S., 2013. Degradation in loesses factors and models. Naukovyi Visnyk Natsionalnoho Hirnychoho Universytetu, 4, pp. 5-12.

\section{Про вплив кількості агрегатів і вільних частинок на просадність лесових грунтів}

\section{Л. С. Коряшкіна ${ }^{1}$, Т. П. Мокрицька², О. В. Бондар ${ }^{2}$, М. М. Одновол ${ }^{1}$}

1 - Державний вищий навчальний заклад „Національний гірничий університет“, м. Дніпро, Україна, e-mail: koriashkinals@gmail.com; odnovol.m.m@nmu.one

2 - Дніпровський національний університет імені Олеся Гончара, м. Дніпро, Україна, e-mail: mokritska@i.ua; olessiabondar@ukr.net

Мета. Вивчення зв'язків між мікроструктурою лесових грунтів і їх просадністю на прикладі плейстоценових відкладів Середнього Придніпров'я.

Методика. Експериментальні й математичні методи досліджень. Агрегатна будова визначена за допомогою вдосконаленої методики Т.Г.Рященко „Мікроструктура“. Показники просідання встановлені відповідно до діючих стандартів України. Дослідження впливу деградації мікроагрегатного складу на просідання проведене з використанням методу групового врахування аргументів.

Результати. Проаналізовані властивості зразків лесоподібних супісків, суглинків і глин, відібраних із відслонень у межах міста Дніпро та Дніпропетровської області (м. Вільногірськ, м. Кривий Ріг, с. Новомиколаївка). Загалом кількість досліджених проб грунту склала 71 одиницю. Додатково до методики досліджень гранулометричного складу дисперсних грунтів уведений спосіб підготовки грунту до аналізу, що надає можливість уточнити область динамічних змін дисперсності. Складовими агрегатів переважно виявилися тонкоглинисті (у дофіновському ( $\left.e P_{\mathrm{III}} \mathrm{df}\right)$, удайському ( $\left.v d P_{\mathrm{III}} \mathrm{ud}\right)$, дніпровському ( $v d P_{\mathrm{II}} \mathrm{dn}$ ) горизонтах) і крупнопилуваті частинки (вітачевський горизонт $e P_{\mathrm{III}} \mathrm{vt}$ ), що й вивільняються при руйнуванні агрегатів у процесі просідання грунту. Побудову функціональної залежності просідання лесових грунтів у зоні аерації за рахунок збільшення вологості здійснено за допомогою методу групового обліку аргументів. При цьому розглядалися різні варіанти вибору незалежних змінних. По-перше, ураховувалися стандартні показники дисперсності та фізичних властивостей грунту. На другому етапі розглядалися чотири варіанти набору змінних - вологість, вміст окремих фракцій або зміни вмісту фракцій як наслідок компресійного випробування. Доведено, що розподіл вільних і зв'язаних частинок, агрегатів піщаних, пилуватих і глинистих фракцій лесових грунтів Середнього Придніпров'я, поряд з показниками фізичного стану грунту, впливають на величини відносної просадності горизонтів. Крім того, незалежно від генезису грунту, на значення його просадності суттєво 
впливають фізичний стан і дисперсність. Побудована функціональна залежність підтверджує більш вагоме значення вологості й щільності грунту, ніж вміст фракцій. Результати дослідження показують, що вміст пов'язаних тонких пилуватих і глинистих частинок і агрегатів є фактором просідання на етапі втрати структурної міцності (0,1 МПа) та в зоні дії додаткових навантажень. Закономірним $є$ й зменшення розмірів частинок, що вивільняються з ростом тиску. Однак ця закономірність порушується в зонах техногенного перетворення структури грунту.

Наукова новизна. Полягає у виявленні функціональної залежності просідання лесоподібних відкладів плейстоцену від деградації мікроагрегатного складу в усьому інтервалі дискретності твердої фази.

Практична значимість. Полягає в експериментальному й теоретичному обгрунтуванні необхідності прогнозу деградації просадових властивостей лесоподібних грунтів у зоні аерації, викликаної зміною мікроагрегатного складу в усьому діапазоні твердої фази.

Ключові слова: мікроагрегати, просідання, лесові грунти, метод групового врахування аргументів

\section{О влиянии количества агрегатов и свободных частиц на просадочность лессовых грунтов}

\section{Л. С. Коряшкина ${ }^{1}$, Т. П. Мокрицкая², О. В. Бондарь ${ }^{2}$, Н. Н.Одновол $\Omega^{1}$}

1 - Государственное высшее учебное заведение „Национальный горный университет“, г. Днепр, Украина, e-mail: koriashkinals@gmail.com; odnovol.m.m@nmu.one

2 - Днепровский национальный университет имени Олеся Гончара, г. Днепр, Украина, e-mail: mokritska@i. ua; olessiabondar@ukr.net

Цель. Изучение связей между микроструктурой лессовых грунтов и их просадочностью на примере плейстоценовых отложений Среднего Приднепровья.

Методика. Экспериментальные и математические методы. Агрегатное строение определено с помощью усовершенствованной методики Т.Г.Рященко „Микроструктура“. Показатели просадочности установлены в соответствии с действующими стандартами Украины. Исследование влияния деградации микроагрегатного состава на проседание грунта проведено с применением метода группового учета аргументов.

Результаты. Проанализированы свойства образцов лессовидных супесей, суглинков и глин, отобранных в пределах города Днепр и Днепропетровской области (г. Вольногорск, г. Кривой Рог, с. Новониколаевка). Общее количество исследованных образцов грунта - 71 единица. Дополнительно к методике исследований гранулометрического состава дисперсных грунтов предложен способ подготовки грунта к анализу, который позволяет уточнить область динамических изменений дисперсности. Составляющими агрегатов преимущественно оказались тонкоглинистые (в дофиновском (e $\left.P_{\mathrm{III}} d f\right)$, удайском $\left(v d P_{\mathrm{III}} u d\right)$, днепровском $\left(v d P_{\mathrm{II}} d n\right)$ горизонтах) и крупнопылеватые частицы (витачевський горизонт $\left.e P_{\text {III }} v t\right)$, которые и высвобождаются при разрушении агрегатов в процессе проседания почвы. Построение функциональной зависимости просадочности лессовых грунтов в зоне аэрации за счет увеличения влажности осуществлено с помощью метода группового учета аргументов. При этом рассмотрены различные варианты выбора независимых переменных. В первую очередь учитывались стандартные показатели дисперсности и физические свойства почвы. На втором этапе рассматривались четыре варианта набора переменных - влажность, содержание отдельных фракций или изменение содержания фракций как следствие компрессионного испытания. Установлено, что распределение свободных и связанных частиц, агрегатов песчаных, пылеватых и глинистых фракций лессовых грунтов Среднего Приднепровья, наряду с показателями физического состояния грунта, влияют на величины относительной просадочности горизонтов указанного региона. Физическое состояние и дисперсность существенно влияют на значение просадочности, независимо от генезиса грунта. Построенная в работе функциональная зависимость подтверждает более весомый вклад в величину лессовой просадочности таких параметров как влажность и плотность грунта, а не содержание фракций. Результаты исследования показывают, что состав связанных тонких пылеватых и глинистых частиц также являются фактором просадочности на этапе потери структурной прочности $(0,1 \mathrm{MПа)} \mathrm{и} \mathrm{в} \mathrm{зоне} \mathrm{действия} \mathrm{дополнительных}$ нагрузок. Закономерным оказалось и уменьшение размеров высвобождаемых частиц с ростом давления. Хотя эта тенденция нарушается при техногенном изменении структуры грунта.

Научная новизна. Заключается в выявлении функциональной зависимости между просадочностью лессовидных отложений плейстоцена и деградацией микроагрегатного состава во всем интервале дискретности твердой фазы.

Практическая значимость. Состоит в экспериментальном и теоретическом обосновании необходимости прогноза деградации просадочных свойств лессовидных грунтов в зоне аэрации, вызванной изменением микроагрегатного состава во всем диапазоне твердой фазы.

Ключевые слова: микроагрегат, просадочность, лессовый грунт, метод группового учета аргументов

Рекомендовано до публікаціі докт. техн. наук М.О.Алєксєєвим. Дата надходження рукопису 09.10.17. 